\title{
Removal of Cd(II) from Aqueous Solutions by Biosorption of Laurencia Papillosa
}

\author{
MAHMOOD NIAD $^{* 1}$, MEHDI MOHAMMADI $^{2}$, ELHAM GHATEE $^{1}$ and SAEID ZAREE ${ }^{1}$
}

${ }^{1}$ Department of Chemistry, Faculty of Science, Persian Gulf University, Bushehr 75169, Islamic Republic of Iran

${ }^{2}$ Persian Gulf Research and Studies Center, Persian Gulf University, Bushehr 75169, Islamic Republic of Iran

mahmoodniad@yahoo.com

Received 13 April 2013 / Accepted 6 May 2013

\begin{abstract}
Biosorption properties of Laurencia papillosa were investigated as a function of $\mathrm{pH}$, temperature and concentration of algal dosage. Kinetics and equilibrium isotherms were studied to estimate the ability of the biosorbent. The cadmium(II) uptake by the biosorbent was best described by pseudo-second-order rate and Langmuir isotherm curve provide more suitable results with respect to the Freundlich isotherm curve.
\end{abstract}

Keywords: Biosorption, Cadmium, Freundlich isotherm, Green algae, Laurencia papillosa, Langmuir isotherm

\section{Introduction}

The pollution of the environment with toxic heavy metals is spreading through the world along with industrial progress ${ }^{1}$. Toxic metals are metals that form poisonous soluble compounds without biological role ${ }^{2}$. Biosorption employed the natural origin material for removal of heavy metals from environment. The biosorption of toxic heavy metals has received considerable attentions in recent years ${ }^{3-4}$.

Among toxic heavy metals, cadmium is one of the most dangerous elements for human health. Cadmium used as corrosion resistant in protective coating for iron, steel and copper ${ }^{5}$. It can enter the human body by eating, drinking, breathing and smoking. By entering the cadmium in the body, it causes serious damage to kidney and bones. It also causes high blood pressure, vomiting, diarrhea, coughs and bronchitis ${ }^{6}$.

The major advantages of biosorption include low cost, high efficiency, minimization of chemical and biological sludge, regeneration of biosorbent and the possibility of metal recover $^{7-10}$. Whereas conventional wastewater treatments have several disadvantages including high energy requirements, incomplete metal removal and running $\operatorname{costs}^{11}$. 
Among the various types of biosorbents, algae possess a high metal-binding capacity. This is due to the presence of various functional groups which can act as binding sites for metals $^{12-13}$. In this work, by employing the Laurencia papillosa from Persian Gulf as biosorbent, we have studied the possibility of the removal of cadmium from aqueous solutions.

\section{Experimental}

Laurencia papillosa was collected from the Persian Gulf on Bushehr Island. Before use, it was washed several times with distilled water to remove dirt. The clean algae was dried in an oven at $60{ }^{\circ} \mathrm{C}$ for $24 \mathrm{~h}$ and powdered to maximize the surface of absorption. The various concentrations were prepared by dissolving an accurate quantity of $\mathrm{CdCl}_{2} \cdot 2 \mathrm{H}_{2} \mathrm{O}$ in deionized distilled water.

Two batches of experiments were done to study the effect of parameters and estimate the optimum qualifications for biosorption process. Cadmium solutions with different concentration, such as: $10,20,85$ and 150 and $170 \mathrm{ppm}$ were used. Also different value of algal dosage such as: 12.5, 25, 112.5, 200 and $320 \mathrm{mg} / \mathrm{L}$ were used.

The experiments were performed in conical flasks with distinct values of biomass. The $p \mathrm{H}$ value was adapted by addition sodium hydroxide or hydrochloric acid. The effect of $p \mathrm{H}$ on cadmium biosorption was studied by varying the $\mathrm{pH}$ at 1, 2, 5, 8, 10 and 12 .

The effect of temperature was studied on cadmium biosorption by varying the temperatures at $4,40,60$ and $75{ }^{\circ} \mathrm{C}$. The effect of algal dosage was studied on cadmium biosorption by variation of algal dosage in 12.5, 25, 112.5, 200 and $320 \mathrm{mg} / \mathrm{L}$.

The cadmium solution and biosorbent were in contactand then filtered. The concentration of cadmium(II) in the solution before and after the equilibrium was determined by an atomic absorption spectrometer (Varian SpectrAA.200 model). The metal uptake $\mathrm{q}_{\mathrm{e}}$ (milligram of metal adsorbed per gram of adsorbent) was calculated from the mass balance equation as $\mathrm{Eq}(1)$

$$
q_{e}=\left(C_{i}-C_{e}\right) V / 1000 \mathrm{~W}
$$

Where $C_{i}(\mathrm{mg} / \mathrm{L})$ is the initial concentration, $C_{e}(\mathrm{mg} / \mathrm{L})$ is the metal concentrations at equilibrium, $\mathrm{V}(\mathrm{mL})$ is the volume of the solution and $\mathrm{W}(\mathrm{g})$ is the mass of sorbent ${ }^{14}$.

\section{Results and Discussion}

\section{The effect of $\mathrm{pH}$}

Concentration of cadmium(II) after absorbance $(\mathrm{mg} / \mathrm{L})$ at various $p \mathrm{H}$ was shown in Figure 1. In acidic conditions i.e. $p \mathrm{H}=1$ and $p \mathrm{H}=2$, the absorbance of cadmium (II) was low because the $\mathrm{H}_{3} \mathrm{O}^{+}$compete with the cadmium (II) to occupy the activated sites on biosorbents. In basic conditions, the absorbance decreased again, that can be related to formation of cadmium hydroxide ${ }^{15-17}$.

\section{The effect of temperature}

Temperature is found to be a critical parameter in the biosorption of cadmium(II) as shown in Figure 2. The maximum cadmium(II) biosorption occurred at $60{ }^{\circ} \mathrm{C}$ which decreased continuously by increasing temperature. For lower temperature, the absorbance of cadmium(II) will be decreased continuously that can be related to the mobility of active cite of alga composition with metal, and for upper temperature, the absorbance of cadmium(II) will be decreased that can be related to the destruction of alga composition ${ }^{18}$. 


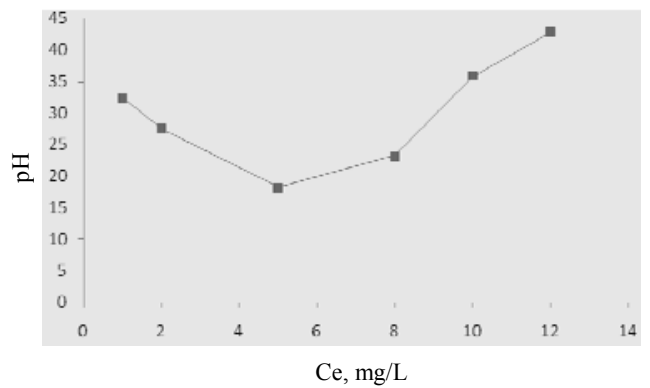

Figure 1. Effect of $\mathrm{pH}$ on $\mathrm{Cd}(\mathrm{II})$ uptake by Laurencia papillosa (initial concentration $=8 \mathrm{ppm}$, biomass $=200 \mathrm{mg} / \mathrm{L}$, temperature $=40^{\circ} \mathrm{C}$, contact time $=40$ minute)

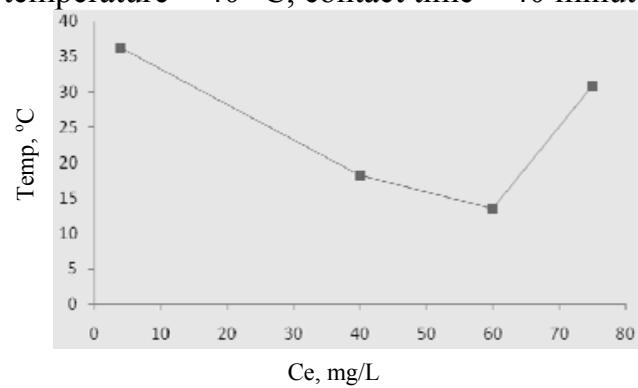

Figure 2. Effect of temperature on $\mathrm{Cd}(\mathrm{II})$ uptake by Laurencia papillosa (initial concentration $=85 \mathrm{ppm}$, biomass $=112.5 \mathrm{mg} / \mathrm{L}, p \mathrm{H}=5$, contact time $=38$ minute)

\section{The effect of algal dosage}

The concentration of cadmium(II) after absorbance as a function of adsorbent dosage was shown in Figure 3. It was apparent that the removal of cadmium(II) increased with increasing algal dosage because of the more availability of the biosorbents. In the beginning, the trend of the curve was changed significantly that can be related to the high number of unoccupied active cite of alga composition. At the end, this trend was changed smoothly that can be related to the saturation of active cite of alga composition ${ }^{19-20}$.

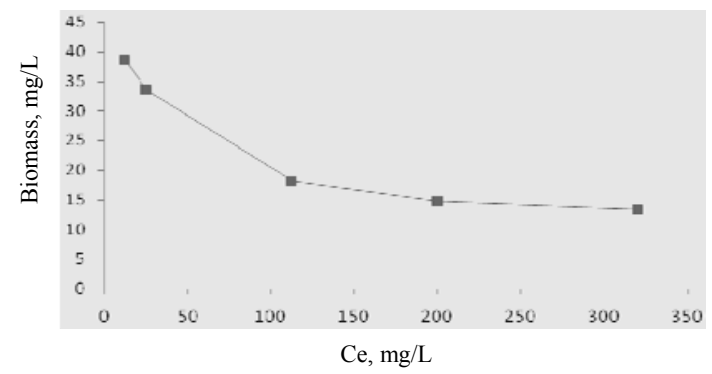

Figure 3. Effect of biosorbent dose on Cd(II) uptake by Laurencia papillosa (initial concentration $=85 \mathrm{ppm}, \mathrm{pH}=5$, temperature $=40^{\circ} \mathrm{C}$, contact time $=38$ minute)

\section{The kinetic of biosorption}

The kinetics of adsorption describes the rate of cadmium ions uptake on green alga which controls the equilibrium time. The results of kinetic studies employed for identification of the mechanism of solute adsorption onto sorbents. 
The sorption data of cadmium(II) uptake by Laurencia papillosa was fitted using Lagergren pseudo first order model (Figure 4) and pseudo second order model (Figure 5). The linearized form of first order Lagergren equation is given as Eq. 2.

$$
\log \left(q_{e}-q_{t}\right)=-\left(k_{1, \text { ads }} t\right) / 2.303+\log q_{e}
$$

and the pseudo second order model is given as Eq. 3.

$$
t / q_{t}=t / q_{e}+\left(1 / k_{2, a d s} q_{e}^{2}\right)
$$

Where $\mathrm{q}_{\mathrm{e}}$ is the mass of metal adsorbed at equilibrium ( $\left.\mathrm{mg} \mathrm{g}^{-1}\right), \mathrm{q}_{\mathrm{t}}$ the mass of metal at time $\mathrm{t}$ (min.), $\mathrm{k}_{1}$, ads the first-order reaction rate of adsorption $\left(\mathrm{min}^{-1}\right), \mathrm{k}_{2}$, ads the pseudosecond-order rate constant of adsorption $\left(\mathrm{mg} \mathrm{g}^{-1} \mathrm{~min}^{-1}\right)^{21-22}$.

The results of Figures 4 and 5 for both algae concentrations i.e. 112.5 and $200 \mathrm{mg} / \mathrm{L}$ for two models were found in Table 1 . The close agreement between the experimental $\mathrm{q}_{\mathrm{e}}\left(\mathrm{mg} \mathrm{g}^{-1}\right)$ values and the estimated $\mathrm{q}_{\mathrm{e}}\left(\mathrm{mg} \mathrm{g}^{-1}\right)$ values from pseudo second-order kinetic model suggested kinetic data followed the pseudo-second order. Also the coefficient of correlation $\left(\mathrm{R}^{2}\right)$ for the pseudo second-order kinetic model is more suitable than the pseudo-first-order model $^{23-24}$.

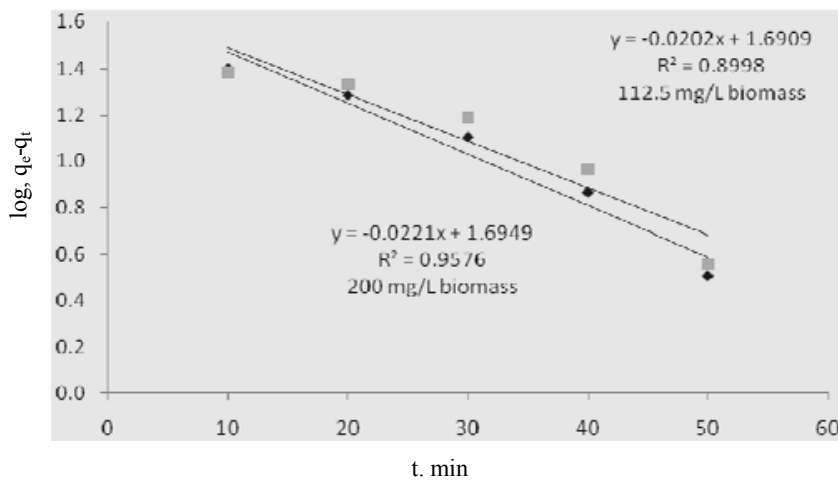

Figure 4. Pseudo-first-order sorption kinetic plots on $\mathrm{Cd}(\mathrm{II})$ uptake for $112.5 \mathrm{mg} / \mathrm{L}$ and $200 \mathrm{mg} / \mathrm{L}$ of Laurencia papillosa (initial concentration $=150 \mathrm{ppm}$, biomass $=25 \mathrm{mg} / \mathrm{L}$, temperature $=25^{\circ} \mathrm{C}, \mathrm{pH}=8$ )

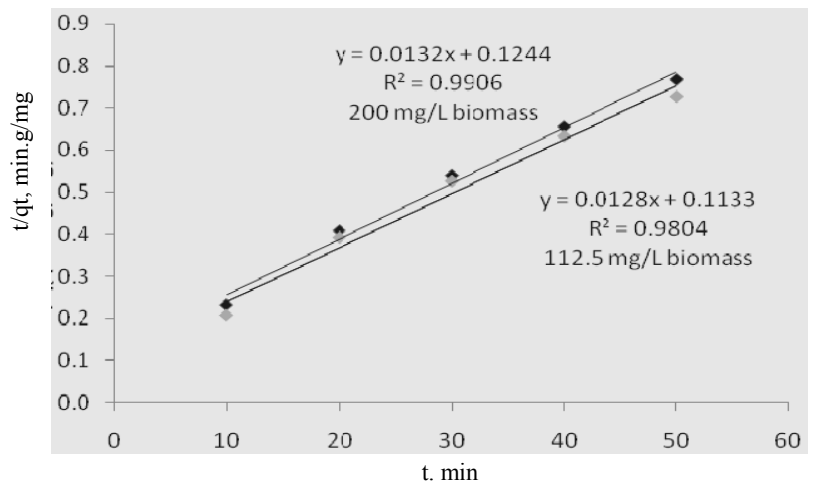

Figure 5. Pseudo-second-order sorption kinetic plots on Cd(II) uptake for $112.5 \mathrm{mg} / \mathrm{L}$ and $200 \mathrm{mg} / \mathrm{L}$ of Laurencia papillosa (initial concentration $=150 \mathrm{ppm}$, biomass $=25 \mathrm{mg} / \mathrm{L}$, temperature $=25^{\circ} \mathrm{C}, \mathrm{pH}=8$ ) 
Table 1. Comparison of the kinetic results for experimental, pseudo-first order and pseudosecond order of Cd(II) uptake by Laurencia papillosa

\begin{tabular}{cccccccc}
\hline parameter & Experimental & \multicolumn{3}{c}{$\begin{array}{c}\text { Pseudo-first-order kinetic } \\
\text { model }\end{array}$} & \multicolumn{3}{c}{$\begin{array}{c}\text { Pseudo-second-order } \\
\text { kinetic model }\end{array}$} \\
\hline $\begin{array}{c}\text { Algae } \\
\begin{array}{c}\text { concentration } \\
\mathrm{mg} \mathrm{L}^{-1}\end{array}\end{array}$ & $\begin{array}{c}\mathrm{q}_{\text {eexp }} \\
\mathrm{mg} \mathrm{g}^{-1}\end{array}$ & $\begin{array}{c}\mathrm{q}_{\text {ecal }} \\
\mathrm{mg} \mathrm{g}^{-1}\end{array}$ & $\begin{array}{c}\mathrm{K}_{2, \text { ads }} \\
\mathrm{g} \mathrm{mg}^{-1}\end{array}$ & $\mathrm{R}^{2}$ & $\begin{array}{c}\mathrm{q}_{\text {ecal }} \\
\mathrm{mg} \mathrm{g}^{-1}\end{array}$ & $\begin{array}{c}\mathrm{K}_{2, \text { ads }} \\
\mathrm{g} \mathrm{mg}^{-1}\end{array}$ & $\mathrm{R}^{2}$ \\
\hline 112.5 & 72.4 & 49.1 & 0.046 & 0.900 & 78.1 & $1.44 \times 10^{-3}$ & 0.980 \\
200 & 68.3 & 49.5 & 0.051 & 0.958 & 75.8 & $1.40 \times 10^{-3}$ & 0.990 \\
\hline
\end{tabular}

Adsorption isotherms

Equilibrium studies in adsorption give the capacity of adsorbent. Equilibrium relationships between adsorbent and adsorbate are described by adsorption isotherms ${ }^{25,26}$. In order to study the adsorption isotherm, Langmuir and Freundlich isotherm models were used more than the others such as Temkin, Dubinin-Radushkevich and $\operatorname{Sips}^{27-29}$. The saturated monolayer Langmuir isotherm is expressed as:

$$
q_{e}=q_{\max } b C_{e} /\left(1+b C_{e}\right)
$$

Where $\mathrm{q}_{\max }\left(\mathrm{mg} \mathrm{g}^{-1}\right)$ is the amount of adsorption corresponding to complete monolayer coverage, i.e., the maximum adsorption capacity and $\mathrm{b}\left(\mathrm{L} \mathrm{mg}^{-1}\right)$ are the Langmuir constant. The Langmuir adsorption isotherm assumes that adsorption takes place at specific homogeneous surface sites within the adsorbent and has found successful application in many sorption processes ${ }^{30}$. On the other hand, Freundlich isotherm is expressed as:

$$
q_{e}=K_{f} C_{e}^{1 / n}
$$

In this equation, $\mathrm{K}_{\mathrm{f}}\left(\mathrm{L} \mathrm{g}^{-1}\right)$ and $\mathrm{n}$ are the constants to be determined from this model. The Freundlich isotherm is an empirical equation employed to describe heterogeneous systems. It assumes neither homogeneous site energies nor limited levels of sorption. The Freundlich constants indicate the extent of the adsorption and the degree of nonlinearity between solution concentration and adsorption respectively ${ }^{31-32}$. We plotted corresponding Langmuir and Freundlich curve in Figures 6 and 7. The Langmuir model is better than the Freundlich model, because of the suitable value of regression constant $\left(\mathrm{R}^{2}\right)$ as shown in Table 2 .

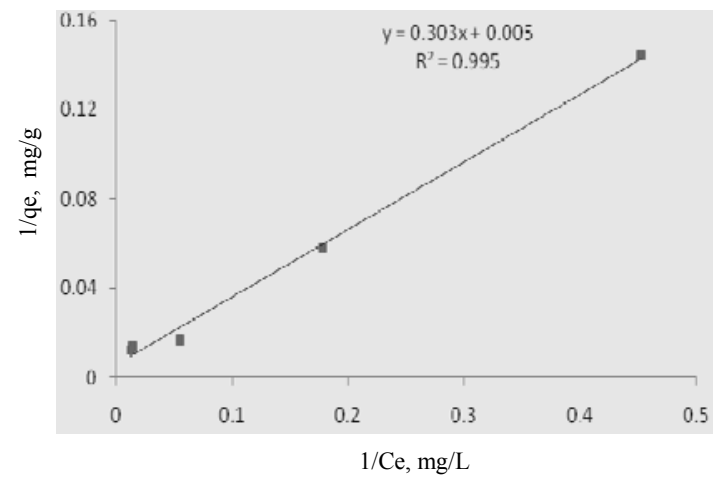

Figure 6. Langmuir adsorption isotherm for Cd(II) uptake on Laurencia papillosa (initial concentration $=8 \mathrm{ppm}$, biomass $=200 \mathrm{mg} / \mathrm{L}$, temperature $=40{ }^{\circ} \mathrm{C}$, contact time $=40$ minute) 


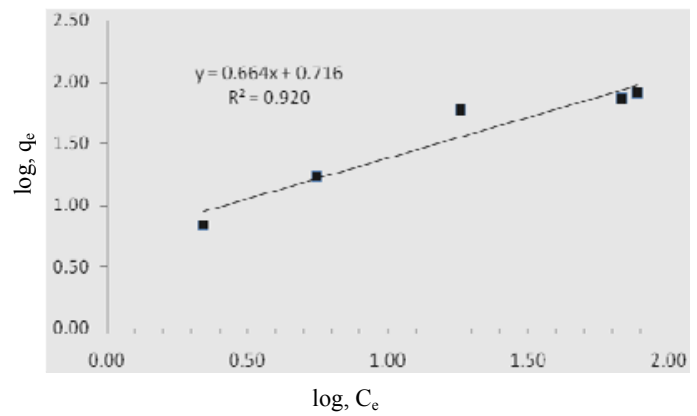

Figure 7. Freundlich adsorption isotherm for Cd(II) on Laurencia papillosa (biomass = $112.5 \mathrm{mg} / \mathrm{L}$, temperature $=40^{\circ} \mathrm{C}$, contact time $=40$ minute)

Table 2. Comparison of Langmuir and Freundlich isotherm parameters for $\mathrm{Cd}(\mathrm{II})$ uptake by Laurencia papillosa

\begin{tabular}{cccc}
\hline \multicolumn{2}{c}{ Freundlich isotherm } & \multicolumn{2}{c}{ Langmuir isotherm } \\
\hline $\mathrm{K}_{\mathrm{f}} \mathrm{mg} \mathrm{g}^{-1}$ & 5.20 & $\mathrm{q}_{\max } \mathrm{mg} \mathrm{g}^{-1}$ & 172.4 \\
$1 / \mathrm{n}^{2}$ & 0.664 & $\mathrm{~b} \mathrm{~L} \mathrm{mg}^{-1}$ & 0.019 \\
$\mathrm{R}^{2}$ & 0.920 & $\mathrm{R}^{2}$ & 0.995 \\
\hline
\end{tabular}

\section{Conclusion}

Biosorption properties of Laurencia papillosa were changed as a function of $p \mathrm{H}$, temperature and concentration of algal dosage. The removal of cadmium(II) increased with increasing temperature until $60^{\circ} \mathrm{C}$, after that the biological ability of biomass and absorbance decreased.

We have concluded that the optimum $p \mathrm{H}$ was 5 and the biosorption increased with increasing algal dosage because of greater availability of biosorbent. Also the biosorption rate of cadmium(II) was relatively rapid in the first $20 \mathrm{~min}$ for solutions with high initial concentration of cadmium(II) and then the rate decreased gradually. The kinetic data followed the pseudo-second order. Furthermore adsorption isotherm fit to Langmuir model. So that adsorption takes place with limited levels homogeneous site of Laurencia papillosa.

\section{Acknowledgement}

The authors wish to be grateful the Persian Gulf university of bushehr for the financial supports for this study.

\section{References}

1. Mata Y N, Blázquez M L, Ballester A, González F and Mũnoz J A, Chem Eng J., 2009, 150(2-3), 289-301; DOI:10.1016/j.cej.2009.01.001.

2. Chouchane S and Snow E T, Chem Res Toxicol., 2001, 14(5), 517-522; DOI: $10.1021 / \mathrm{tx} 000123 \mathrm{x}$.

3. Romera E, Gonzalez F, Ballester A, Blázquez M L and Mũnoz J A, Bioresouce Technol, 2007, 98(17), 3344-3353; DOI:10.1016/j.biortech.2006.09.026.

4. Oubagaranadin J U K, Sathyamurthy N and Murthy Z, J Hazard Mater., 2007, 142(12), 165-174; DOI:10.1016/j.jhazmat.2006.08.001.

5. Barka N, Abdennouri M, Boussaoud A and Makhfouk M E, Desalination, 2010, 258(1-3), 66-71; DOI:10.1016/j.desal.2010.03.046.

6. Kumar J I N, Oommen C and Kumar R N, Am Euras J Agric Enviro Sci., 2009, 6(3), 317-323. 
7. Nordberg G F, Biometals, 2004, 17(5), 485-489;

DOI:10.1023/B:BIOM.0000045726.75367.85

8. Esmaeili A, Ghasemi S and Rustaiyan A, J Marin Sci Technol., 2010, 18(4), 587-592.

9. Padilla A P and Tavani E L, Desalination, 1999, 126, 219.

10. Yabe M J S and Oliveira E D, Adv Environ Res., 2003, 7(2), 263-272; DOI:10.1016/S1093-0191(01)00128-9.

11. Karthikeyan S, Balasubramanian R and Iyer C S P, Bioresouce Technol., 2007, 98(2), 452-455; DOI:10.1016/j.biortech.2006.01.010.

12. Yun Y S, Park D, Park J M and Volesky B, Environ Sci Technol., 2001, 35(21), 4353 4358; DOI:10.1021/es010866k.

13. Kaewsarn P, Chemosphere, 2002, 47(10), 1081-1085;

DOI:10.1016/S0045-6535(01)00324-1.

14. Volesky B and Holan Z R, Biotechnol Prog., 1995, 11(3), 235-250;

DOI:10.1021/bp00033a001.

15. Sari A and Tuzen M, J Hazard Mater., 2009, 164(2-3), 1004-1011;

DOI:10.1016/j.jhazmat.2008.09.002.

16. Altin O, Ozbelge O H and Dogu T, J Chem Technol Biotechnol., 1999, 74(12), 1131-1138; DOI:10.1002/(SICI)1097-4660(199912)74:12<1131::AID-JCTB158>3.0.CO;2-0.

17. Heidari A, Younesi H and Mehraban Z, Chem Eng J., 2009, 153(1-3), 70-79; DOI:10.1016/j.cej.2009.06.016.

18. Jnr M H and Spiff A I, Electron J Biotechn., 2005, 8(2), 162; DOI:10.2225/vol8-issue2-fulltext-4.

19. Alyüz B and Veli S, J Hazard Mater., 2009, 167(1-3), 482-488;

DOI:10.1016/j.jhazmat.2009.01.006.

20. Sari A and Tuzen M, J Hazard Mater., 2009, 171(1-3), 973-979;

DOI:10.1016/j.jhazmat.2009.06.101

21. Lagergren S, Kungliga Svenska Vetenskapsakademiens Handlingar, 1898, 24(4), 1-39.

22. Ho Y S, McKay G, Wase D A J and Foster C F, Adsorpt Sci Technol., 2000, 18, 639-650.

23. Bhatti H N, Mumtaz B, Hanif M A and Nadeem R, Process Biochem., 2007, 42(4), 547-553; DOI:10.1016/j.procbio.2006.10.009.

24. Zubair A, Bhatti H N, Hanif M A and Shafqat F, Water Air Soil Poll., 2008, 191(1-4), 305-318; DOI:10.1007/s11270-008-9626-y.

25. Han R, Zhang J, Zou W, Jie S and Hongmin L, J Hazard Mater, 2005, 125(1-3), 266271; DOI:10.1016/j.jhazmat.2005.05.031.

26. Esmaeili A, Ghasemi S and Rustaiyan A, Afr J Biotechnol., 2008, 7(12), 2034-2037.

27. Apiratikul R and Pavasant P, Bioresouce Technol., 2008, 99(8), 2766-2777; DOI:10.1016/j.biortech.2007.06.036.

28. Cabuk A, Akar T, Tunali S and Gedikli S, Chem Eng J., 2007, 131(1-3), 293-300; DOI:10.1016/j.cej.2006.12.011.

29. Vijayaraghavan K, Padmesh T V N, Palanivelu K and Velan M, J Hazard Mater., 2006, 133(1-3), 304-308; DOI:10.1016/j.jhazmat.2005.10.016.

30. Green-Ruiz C, Rodriguez-Tirado V and Gomez-Gil B, Bioresouce Technol., 2008, 99(9), 3864-3870; DOI:10.1016/j.biortech.2007.06.047.

31. Shaker M A, Am J Appl Sci., 2007, 4(8), 605-612; DOI:10.3844/ajassp.2007.605.612.

32. Vijaya Y, Popuri S R, Boddu V M and Krishnaiah A, Carbohyd Polym., 2008, 72(2), 261-271; DOI:10.1016/j.carbpol.2007.08.010. 